\title{
Badanie wpływu zmian współczynnika szorstkości na wielkość przepływu obliczeniowego
}

\author{
Study the impact of changes in the roughness coefficient on the calculated discharge
}

\author{
Ewa Słowik-Opoka*, Maciej Brożek** \\ *Instytut Ochrony Ekosystemów Leśnych, Uniwersytet Rolniczy im. H. Koltatajaw Krakowie, e.opoka@ur.krakow.pl \\ **Katedra Melioracji i Ksztaltowania Środowiska, Uniwersytet Rolniczy im. H. Kołtątaja w Krakowie
}

\begin{abstract}
Zarys treści: $\mathrm{W}$ pracy podjęto próbę określenia relacji między szorstkością koryta rzeki podgórskiej, wyrażoną współczynnikiem szorstkości a wielkością przepływu obliczeniowego. Z uwagi na fakt, że dobór zawyżonych wartości współczynnika szorstkości $(n)$ może prowadzić do błędnego określania wielkości przepływu oraz wymiarowania przekroi poprzecznych koryt rzek i potoków w ramach pracy wykonano obliczenia wielkości przepływu $(Q)$ z uwzględnieniem wartości $(n)$ obliczonego wg różnych formuł. Przeprowadzone zostały pomiary hydrometryczne oraz geodezyjne. Pobrane zostały próbki rumowiska dennego celem określenia średnic charakterystycznych rumowiska, które posłużyły do obliczeń współczynników: szorstkości (n) oraz oporu przepływu $(f)$ na badanym odcinku rzeki. W oparciu o analizę wyników badań stwierdzono, że decydujący wpływ na wartość współczynnika szorstkości wywiera średnica ziaren. Z uwagi na złożoność zagadnienia, potwierdzenie hipotezy o istnieniu bezpośredniego związku pomiędzy współczynnikiem szorstkości a głębokością wody w korycie wymaga przeprowadzenia dodatkowych badań.
\end{abstract}

Słowa kluczowe: rzeka, przepływ, rumowisko, szorstkość, koryto rzeki

\begin{abstract}
The study attempts to describe the relationship between roughness of mountain river beds, expressed by the roughness coefficient and the water depth of the river. Due to the fact that the selection of inflated values of the coefficient $(n)$ can lead to erroneous determination of the discharge and dimensioning of river cross sections, the discharge $(Q)$ has been calculated using values of $(n)$ which were derived using different formulas. Hydrometric measurements and surveying were performed, samples were also collected to determine dimensions of sediment particles, which were used to calculate the coefficients: roughness $(n)$ and resistance to flow $(f)$ on the tested section of the river. Based on the analysis of test results, it was found that the diameter of grains had the decisive influence on the value of roughness. Due to the complexity of the issue, the confirmation of the hypothesis of the existence of a direct relationship between the ratio of roughness coefficient and the water depth in the river channel requires more research.
\end{abstract}

Key words: river, discharge, bed load, roughness, river channel

\section{Wprowadzenie}

W korytach naturalnych, siła ciężkości wprawiająca wodę w ruch jest równoważona przez siły tarcia, w przeciwnym bowiem razie woda płynęłaby ruchem jednostajnie przyspieszonym, co w warunkach naturalnych nie zachodzi. Opory przepływu w ciekach naturalnych możemy podzielić na opory przepływu dotyczące dna płaskiego bez ruchu rumowiska (dna sztywnego), dna płaskiego z ruchem rumowiska oraz koryt $\mathrm{z}$ dnem rozmywanym, gdzie tworzą się formy denne (Parker, Peterson 1980, Knighton
1984, Hey 1988, Bartnik, Florek 2002, Radecki-Pawlik i in. 2005). Opory przepływu można odnosić zarówno do szorstkości ziaren materiału, z których zbudowane jest dno rzeki, jak i do form dennych, związanych $\mathrm{z}$ ruchem rumowiska (Carling i in. 1992, Aberle, Smart 2003).

Najważniejszymi czynnikami kształtującymi szorstkość koryta są:

(a) siły tarcia między ziarnami,

(b) siły tarcia wody o podłoże,

(c) opory spowodowane geometrią osi koryta wzdłuż biegu rzeki oraz kształtem przekroju poprzecznego, 
(d) opory wynikające $\mathrm{z}$ transportu rumowiska,

(e) opory związane z występowaniem form dennych.

Lau (1988) wiąże szorstkość w korycie głównie z wysokością form dennych oraz zauważa, że im materiał budujący dno jest drobniejszy, tym mniejsza jest rola tarcia pomiędzy ziarnami - zwiększa się natomiast rola szorstkości reliefu dna. Według Dąbkowskiego (1982), opory przepływu nad utworami mobilnymi są dużo mniejsze niż ma to miejsce w przypadku form nieruchomych. Do zbliżonych wniosków doszła Gładki (1976) w oparciu o badania oporów ruchu w korycie. W rozważaniach czynników kształtujących opory ruchu w korytach rzecznych ujmowane jest również zagadnienie wpływu roślinności (Horn, Richards 2007). W korytach rzecznych opory przepływu kształtowane są przez liczne i różnorodne czynniki. Najbardziej kompleksowa ocena szorstkości została opisana metodą Cowana (1956), gdzie współczynnik szorstkości charakteryzujący całkowite opory w korycie rzeki przedstawiony został jako suma współczynników cząstkowych, na które składają się poprawki ze względu na: rodzaj materiału koryta, stopień nieregularności brzegów i koryta, zmiany wielkości i kształtu przekroju poprzecznego rzeki, intensywność wegetacji, stopień zasłonięcia koryta, stopień meandrowania rzeki oraz przeszkody. Również wymiary i kształt przekroju poprzecznego uznawane są za jeden z istotniejszych czynników wpływających na opory przepływu (Godzik 2006).

Z dotychczasowych doświadczeń i badań nad oporami przepływu w korytach rzecznych wynika, iż najskuteczniejszą drogą poznania i oceny tych zjawisk są badania terenowe, obrazujące stan rzeczywisty koryta rzeki (Gładki 1976, Żelazo 1992, Mokwa 2003, Parzonka i in. 2002, Smart i in. 2002, Bezzola i in. 2004). Problematyka oporów przepływu w korytach rzecznych jest zagadnieniem wciąż aktualnym i obecnie nabiera jeszcze większego znaczenia $\mathrm{z}$ uwagi na realizację zadań $\mathrm{w}$ ramach regulacji czy renaturyzacji cieków, stąd badania w tym zakresie powinny być kontynuowane.

Oddzielną problematyką przy wyznaczaniu wielkości przepływu obliczeniowego jest sposób obliczania współczynnika szorstkości. Wybór metody obliczeniowej najczęściej dostosowuje się do dostępnych danych (spadek hydrauliczny, wartość prędkości średniej, kształt przekroju poprzecznego, promień hydrauliczny koryta i in.). $\mathrm{Z}$ punktu widzenia obliczeń projektowych kluczowym zagadnieniem jest sposób określania wielkości współczynnika szorstkości, jako cechy charakteryzującej podłoże (Gładki 1976, Julien i in. 2002). Rice i in. (1998) na podstawie przeprowadzonych badań scharakteryzowali zmiany szorstkości koryta wywołane zmianami, zarówno spadku, średniej średnicy ziaren oraz napełnienia.

Dla stabilnych odcinków koryt utworzonych w gruntach luźnych, drobno i średnioziarnistych (piaski i żwiry) Grišanin (Wołoszyn i in. 1994) zaproponował formułę do obliczenia współczynnika szorstkości (n) z uwzględnieniem tzw. bezwymiarowej głębokości strumienia (M), w której promień hydrauliczny może być zastąpiony głębokością wody w korycie. Współcześnie do obliczeń prędkości średniej w przekroju poprzecznym koryta wykorzystywana jest przez inżynierów zależność Gaucklera-Manninga-Stricklera, w której współczynnik szorstkości wprowadzony przez Stricklera przyjmuje następującą postać: $\mathrm{k}_{\mathrm{St}}=26 / \mathrm{k}^{1 / 6}$, gdzie (k) jest chropowatością bezwzględną powierzchni koryta (m). W krajach anglojęzycznych jest stosowany w miejsce współczynnika Stricklera współczynnik szorstkości Manninga. Obydwa współczynniki łączy zależność: $\mathrm{k}_{\mathrm{St}}=1 / \mathrm{n}$, w której (n) oznacza współczynnik szorstkości Manninga $\left(\mathrm{m}^{-1 / 3} \cdot \mathrm{s}\right)$. Jednakże Naudasher (1992) w swojej pracy wskazuje na istotne ograniczenia stosowalności współczynników szorstkości w aspekcie obliczania prędkości średniej. Autor w swojej pracy stwierdza m.in., że wprowadzane do obliczeń prędkości średniej (a następnie przepływu) współczynniki szorstkości nie uwzględniają lepkości wody, więc zależności pomiędzy prędkością średnią a szorstkością mają miejsce tylko w warunkach przepływu hydraulicznie szorstkiego. Współczynniki szorstkości nie uwzględniają tzw. chropowatości względnej koryta, czyli relacji pomiędzy chropowatością powierzchni koryta a głębokością wody w korycie. Co więcej, nie są one bezwymiarowe i są wyznaczone dla jednego określonego napełnienia a promień hydrauliczny nie jest wystarczającą charakterystyką kształtu przekroju strumienia (Kubrak 2006). Do obliczeń średniej prędkości przepływu w korytach otwartych, pomimo pewnych niedoskonałości, stosuje się uniwersalne równanie Darcy-Weisbacha zapożyczone $\mathrm{z}$ hydrauliki przewodów zamkniętych, w którym bezwymiarowy współczynnik oporów (f) w tym równaniu uwzględnia lepkość wody oraz chropowatość ścian.

\section{Obszar badań}

Raba jest prawostronnym dopływem górnej Wisły i przepływa przez trzy regiony hydrograficzne Polski: Karpaty Zewnętrzne - Beskidy, Pogórze Karpackie oraz Kotlinę Sandomierską. Zlewnia Raby ma powierzchnię 1537 km², a długość rzeki wynosi $137 \mathrm{~km}$, przy średnim spadku 4,42\%o. W strefie karpackiej znajduje się $86 \%$ powierzchni zlewni. Źródła Raby leżą na wysokości 756 m n.p.m. w pobliżu miejscowości Obidowa. Wzdłuż rzeki Raby, na odcinku długości 19 km do miejscowości Uście Solne nie ma dopływów, zlewnia jest wąska, o średniej szerokość $3 \mathrm{~km}$.

Badania przeprowadzono na ujściowym odcinku rzeki Raby o długości 650 m i spadku 2\%o, położonym na obszarze powiatu bocheńskiego (gmina Szczurowa) w miejscowości Uście Solne (ryc. 1). Na odcinku tym wyodrębnione zostały dwa przekroje, tj. przekrój „,Wodopój” (W) w km 0+700 m oraz przekrój ,ujście” (U) w km 0+50 m. Szerokość koryta rzeki w miejscu prowadzonych badań wynosi $50 \mathrm{~m}$. Podczas pomiarów terenowych średnie napełnienie wodą w korycie wynosiło 1,0 m.

Rzeki karpackie, w tym Raba charakteryzują się bardzo silnie zróżnicowanymi przepływami średnimi dobo- 


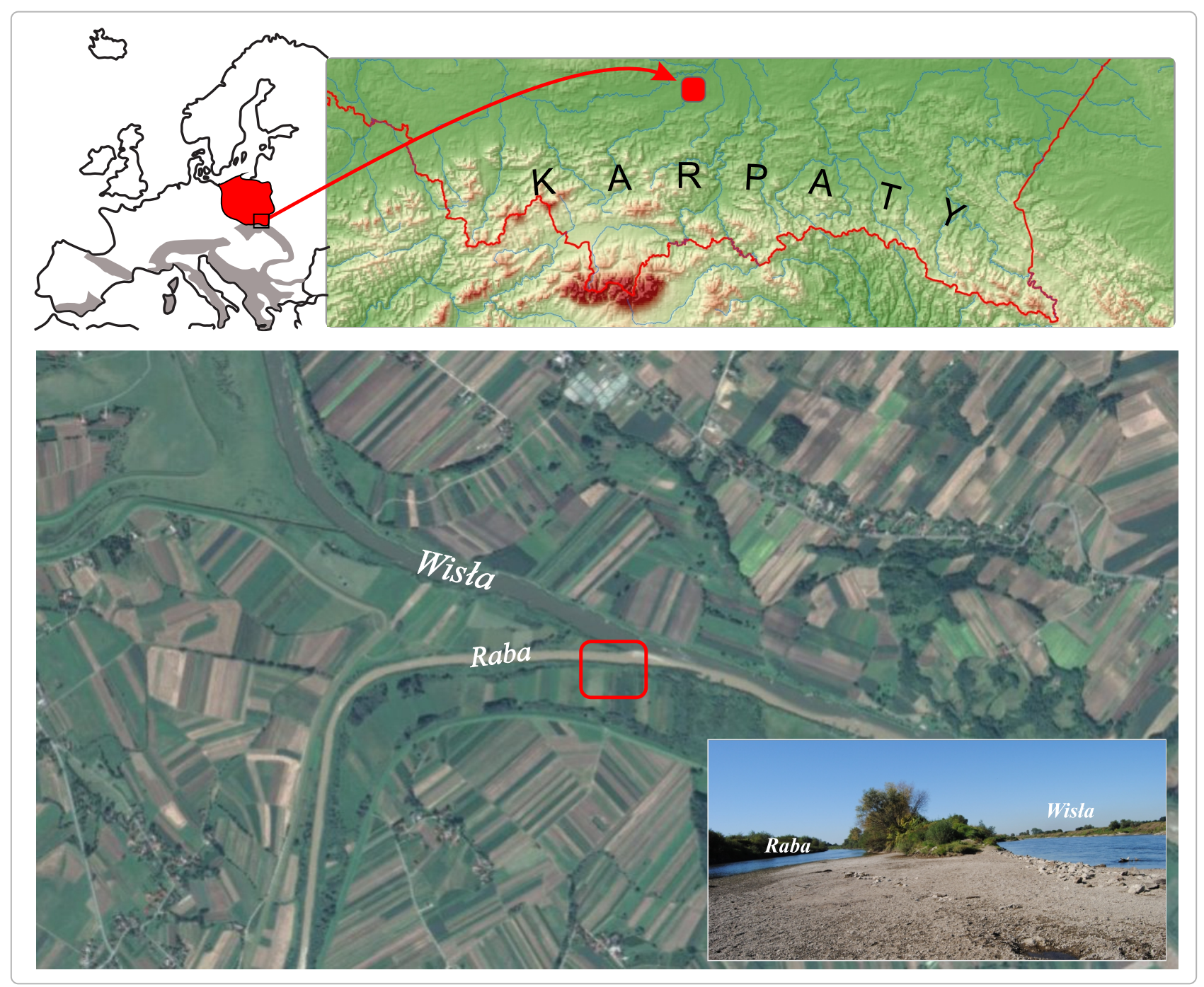

Ryc. 1. Lokalizacja obiektu badań

Fig. 1. The location of the object of research

wymi. Wezbrania w zlewniach górskich są gwałtowne i trwają stosunkowo krótko. W przypadku rzeki Raby charakterystycznym jest reżim rzeczny pluwialno-niwalny (średni odpływ miesiąca letniego jest wyższy od średniego odpływu miesiąca wiosennego i wynosi 130180\% średniego odpływu rocznego (Dynowska 1971). Jak podaje Wrzesiński (2010), w przypadku polskich rzek współczynnik stabilności pojawiania się fazy wezbrań i niżówek wykazuje dość charakterystyczne przestrzenne zróżnicowanie. Regularność pojawiania się fazy niżówek jest mniejsza niż wezbrań. Na większości rzek tzw. pierwsze minimum (I min) pojawia się najczęściej w okresie letnim (VI-VIII) i letnio-jesiennym (VII-IX). Późniejszy termin I min obserwuje się na rzekach na południu kraju, m.in. na Rabie (X-I). Faza wezbrań reżimu rzek, wyrażona III max jest przeważnie względnie stabilna, natomiast względnie niestabilnym okresem III max charakteryzują się rzeki górskie w Karpatach (Raba, Wisłok, San). Przepływ średni niski, obliczony wg formuły Stachy (Punzet 1981) (SNQ) wynosi $2,7 \mathrm{~m}^{3} \cdot \mathrm{s}^{-1}$, natomiast dla stacji w Proszówkach $6,7 \mathrm{~m}^{3} \cdot \mathrm{s}^{-1}$. Przepływ średni roczny (SSQ) jest równy $20,9 \mathrm{~m}^{3} \cdot \mathrm{s}^{-1}$ (wg wzoru
Krzanowskiego 1972) oraz $19,3 \mathrm{~m}^{3} \cdot \mathrm{s}^{-1}$ (wg wzoru Punzeta). Przepływ minimalny $\mathrm{Q}_{\min 50 \%}$ jest równy $1,39 \mathrm{~m}^{3} \cdot \mathrm{s}^{-1}$ (Słowik-Opoka 2006).

W litologii obszaru badań przeważają utwory gruboklastyczne, wśród których przeważają piaskowce karpackie. Na całym odcinku objętym badaniami zaznacza się zróżnicowanie wielkości okruchów rumowiska, tj. od otoczaków, przez drobne i grube żwiry do piasków.

\section{Materiały i metody}

Metodyka pracy obejmowała wykonanie pomiarów terenowych, prac laboratoryjnych oraz obliczeń. W ramach pomiarów terenowych wykonano pomiary hydrometryczne oraz geodezyjne. Położenie przekroi poprzecznych koryta stabilizowano za pomocą palików drewnianych, w sąsiedztwie których kotwiono dodatkowo pręty stalowe o długości 1,20 m, do których doczepiana była lina. Lina dowiązana do pręta na brzegu prawym była następnie przeciągana i mocowana do pręta na brzegu lewym rzeki. Naciąg liny uzyskano dzięki użyciu stalo- 
wej sprężyny. Lina na całej długości została oznakowana $\mathrm{w}$ odstępach co $3 \mathrm{~m}$ celem zagwarantowania niezmienności położenia pionów hydrometrycznych podczas każdorazowego wykonywania pomiarów prędkości chwilowych. Ponadto, wykonano pomiary geodezyjne przekroi poprzecznych koryta oraz całego odcinka badawczego. Metodyka przeprowadzonych pomiarów geodezyjnych oraz ich zakres zostały szczegółowo opisane w pracy Salaty (2012).

Zasadniczym celem prac $\mathrm{w}$ terenie było wykonanie pomiarów prędkości chwilowych w pionach, które przeprowadzono z użyciem młynka hydrometrycznego. Pomiar prędkości wykonywano na różnych głębokościach od dna. W celu przeprowadzenia analizy składu granulometrycznego materiału dennego wzdłuż przekroju „wodopój” (W) pobrano próbki rumowiska dennego z trzech stref, tj. ze strefy przy brzegu prawym (próbka A), przy brzegu lewym (C) oraz z części środkowej koryta (próbka B). Analogicznie, pobrano próbki z przekroju „ujście” (U), tj. próbki D, F i E. Prace wykonywane były przy niskich stanach wody.

W laboratorium wykonano badania składu ziarnowego próbek rumowiska dennego. Próbki suszono w temperaturze $105^{\circ} \mathrm{C}$ do masy stałej, ważono a następnie metodą przesiewu (wg PN-EN 933-1:2012) określono ich skład frakcyjny.

Bazując na wynikach prac terenowych, w tym na wynikach pomiarów prędkości chwilowych w ramach prac kameralnych wykreślono izotachy metodą krigingu w programie Surfer oraz przystąpiono do wykonania obliczeń, m.in. współczynnika szorstkości $(n)$ wg przedstawionych poniżej formuł:

1) formuła Grišanina, służąca obliczeniu współczynnika (n) z wyznaczeniem bezwymiarowej głębokości, postaci:

$$
\begin{gathered}
n=M^{2}\left(\frac{\lambda I}{g}\right)^{\frac{1}{2}} \cdot \frac{1}{H^{\frac{1}{3}}} \\
M=\frac{R_{h}(g \lambda)^{\frac{1}{4}}}{Q^{\frac{1}{2}}}
\end{gathered}
$$

gdzie:

$M$ - bezwymiarowa głębokość wody,

$\lambda$ - obwód zwilżony lub szerokość zwierciadła wody,

$I$ - spadek hydrauliczny,

$g$ - przyspieszenie ziemskie,

$R_{h}$ - promień hydrauliczny lub napełnienie $H$,

$Q$ - natężenie przepływu wody.

Parametr $(M)$ w pracy został obliczony w czterech wariantach, mianowicie:

1) $\mathrm{M}_{1}$ - dla $Q_{1}$ oraz $H=R_{h}$

2) $\mathrm{M}_{2}-$ dla $Q_{2}$ oraz $H=R_{h}$,

3) $\mathrm{M}_{3}$ - dla $Q_{1}$ oraz $H$ oraz

4) $\mathrm{M}_{4}-$ dla $Q_{2}$ oraz $H$.
Analogicznie, współczynnikowi szorstkości $(n)$ nadano indeksy: $n_{1}, n_{2}, n_{3}, n_{4}$. Wielkość przepływu obliczeniowego $\left(Q_{1}\right)$ została obliczona z uwzględnieniem prędkości średniej w przekroju $\left(v_{\text {sr. }}\right)$ oraz jego pola powierzchni $(F)$, natomiast przepływu $\left(Q_{2}\right)$ - na podstawie danych IMGW (dla stacji w Proszówkach);

2) formuła Stricklera, uwzględniająca średnicę miarodajną $\left(d_{m}\right)$ (Parzonka i in. 2002), postaci:

$$
\begin{gathered}
n=\frac{1}{k} \\
\mathrm{k}=\frac{21,1}{\sqrt[6]{d_{50}}}
\end{gathered}
$$

gdzie:

$n$ - współczynnik szorstkości $\left(n_{5}\right)$,

$k$-współczynnik Stricklera,

$d_{50}$ - średnica miarodajna $(\mathrm{m})$;

3) formuła Stricklera w modyfikacji Gładki-Gawora (Gładki i in. 1981):

$$
\begin{gathered}
n=0,067 \cdot k_{s}^{0,33} \\
k_{s}=2,54 \cdot d_{80}
\end{gathered}
$$

gdzie:

$n$ - współczynnik szorstkości Manninga $\left(n_{6}\right)$,

$k_{s}$ - bezwzględna szorstkość dna,

$d_{80}^{s}$ - średnica ziaren $(\mathrm{m})$;

4) formuła Chow (Ven Te Chow 1959), uwzględniająca wartość prędkości chwilowej i maksymalne napełnienie:

$$
\begin{gathered}
n=\frac{(\mathrm{x}-1) \cdot y^{\frac{1}{6}}}{6,78 \cdot(\mathrm{x}+0,95)} \\
\mathrm{x}=\frac{v_{0,8}}{v_{0,2}}
\end{gathered}
$$

gdzie:

$n$ - współczynnik szorstkości $\left(n_{7}\right)$,

$y$ - maksymalne napełnienie w przekroju (m),

$v_{0,2}$ - wartość zmierzonej prędkości na wysokości 0,2 y $\left(\mathrm{m} \mathrm{s}^{-1}\right)$,

$v_{0,8}$ - wartość zmierzonej prędkości na wysokości 0,8 y $\left(\mathrm{m} \cdot \mathrm{s}^{-1}\right)$.

Współczynnik oporów przepływu $(f)$ obliczono korzystając z równania Darcy-Weisbacha (Depeweg i in. 2014), postaci:

$$
\begin{gathered}
f=\frac{8 g}{C^{2}} \\
C=21,1 \cdot\left(\frac{R_{h}}{d_{50}}\right)
\end{gathered}
$$


gdzie:

$C$ - współczynnik prędkości obliczany z uwzględnieniem promienia hydraulicznego $R_{h}(\mathrm{~m})$,

$d_{50}-$ średnicy miarodajnej $(\mathrm{m})$,

$g$ - przyspieszenie ziemskie.

W oparciu o wyniki obliczeń współczynnika szorstkości $(n)$ wg różnych formuł obliczono przepływ $(Q)$.

\section{Wyniki}

Badanie składu uziarnienia próbek rumowiska pobranych z trzech stref w przekrojach „wodopój” (A, B, C) oraz „ujście” (D, E, F) wykazało, że wielkość średnicy ziaren kształtowała się w dość szerokim zakresie, tj. od 0,5 do $25 \mathrm{~mm}$ (ryc. 2). Wysokie tempo zmian wielkości średnic miarodajnych od $1 \mathrm{~mm}$ do $10 \mathrm{~mm}$ wskazuje na wzmożony proces transportu rumowiska wzdłuż badanego odcinka, związanego m.in. ze zmianą głębokości i prędkości wody.

Bezwymiarowa głębokość wody $(M)$ obliczona z wykorzystaniem wielkości promienia hydraulicznego $\left(R_{h}\right)$ przyjmuje wartości zbliżone do rzeczywistej głębokości wody w rzece. Wartości wyższe $(M)$ uzyskano w przypadku wykonania obliczeń z użyciem parametru napełnienia $\left(M_{2}, M_{4}\right)$. Przepływ $(Q)$ wyznaczony na podstawie prędkości średniej w przekroju obliczonej w oparciu o pomiary prędkości chwilowej przyjmuje wartości wyższe, w kilku przypadkach blisko dwukrotnie, w porównaniu z przepływem $(Q)$ obliczonym na podstawie danych uzyskanych z IMGW (tab. 1). Rozkład prędkości w dwóch przekrojach ilustruje rycina 3 .
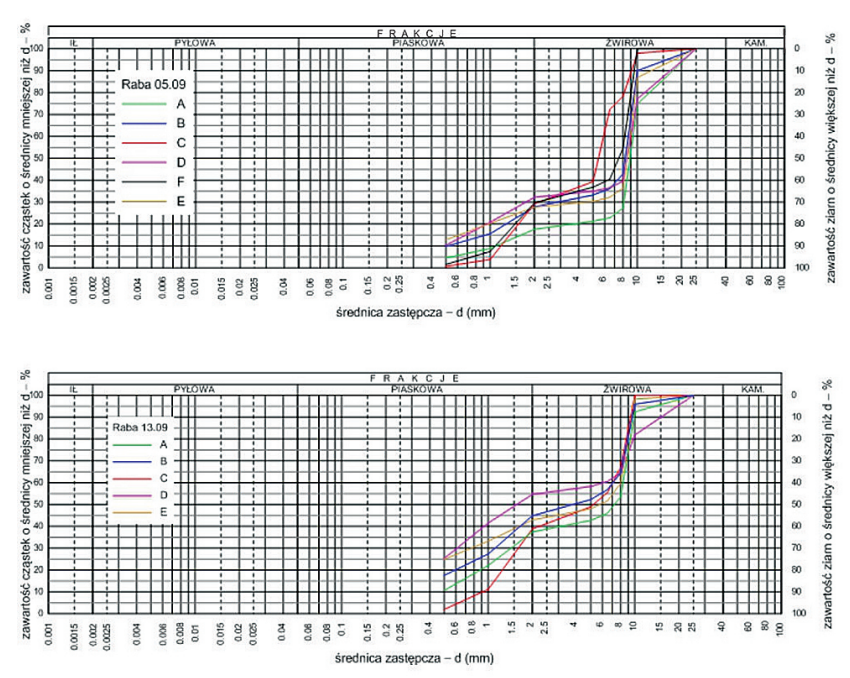

W tabeli 2 zamieszczono wyniki obliczeń współczynnika szorstkości $(n)$ wg różnych formuł. Analizując dane można zauważyć, że najwyższe jego wartości uzyskano przy zastosowaniu do obliczeń formuły Grišanina (Wołoszyn i in 1994), w której zasadnicze znaczenie odgrywa napełnienie wodą $\mathrm{w}$ korycie, stosowane zamiennie z promieniem hydraulicznym. Niższe wartości współczynnika (n) uzyskano przy zastosowaniu do obliczeń wzorów uwzględniających średnice charakterystyczne ziaren $\left(d_{50}\right.$ oraz $\left.d_{80}\right)$, tj. wg formuły Stricklera $\left(n_{5}\right)$ oraz Stricklera w modyfikacji Gładki $\left(n_{6}\right)$. Różnice w wartościach współczynnika $\left(n_{6}\right)$ oraz współczynnika $\left(n_{5}\right)$ wskazują na to, że zależność między współczynnikiem szorstkości a średnicą ziaren przebiega odmiennie od zależności przedstawionej przez Stricklera. Współczynnik szorstkości obliczony wg formuły zaproponowanej przez Gładki przyjmuje wartości zbliżone do współczynnika szorstkości $\left(n_{7}\right)$, obliczonego z uwzględnieniem prędkości chwilowej i głębokości maksymalnej. Zmiany wielkości współczynnika oporu przepływu, związane $\mathrm{z}$ ruchem materiału dennego w przypadku badanego odcinka zmieniała się w zakresie od 0,030 do 0,054 . Wyniki obliczeń współczynnika oporów przepływu na badanym odcinku są zbieżne z wynikami wcześniejszych badań na Rabie (Gładki 1976).

Zmiany wielkości współczynnika szorstkości znalazły odzwierciedlenie w obliczeniach objętości przepływu $(Q)$ (tab. 3). Największe wartości przepływu uzyskano przy uwzględnieniu współczynników szorstkości $\left(n_{6}\right.$ oraz $\left.n_{7}\right)$, tj. obliczonych z użyciem średnicy miarodajnej. Przypuszczalnie, współczynnik przyjęty do obliczeń posiadał cechy współczynnika statycznego. Mniejsze wartości
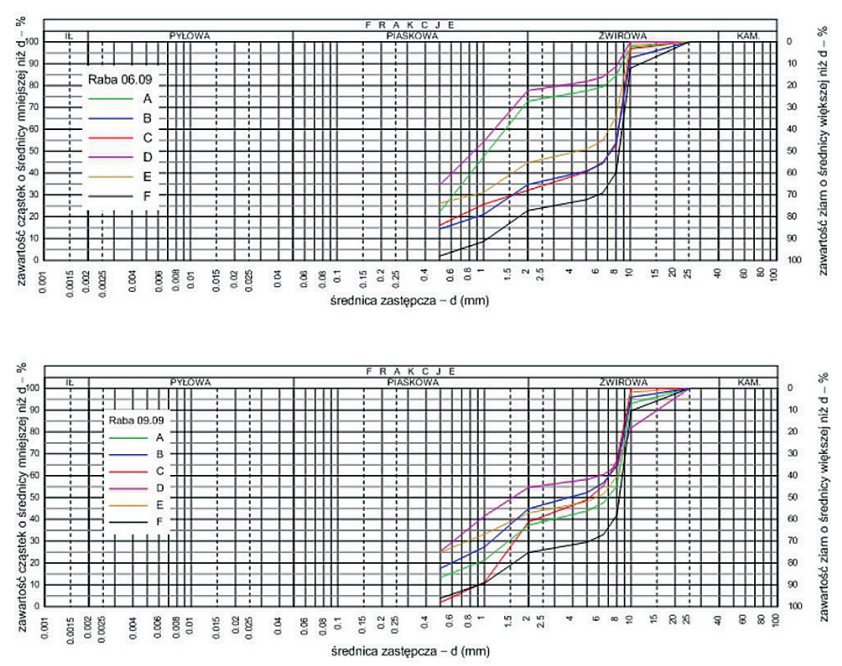

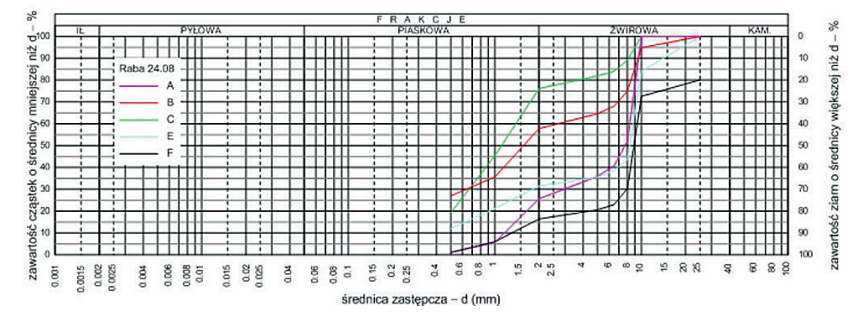

Ryc. 2. Wykresy krzywych uziarnienia rumowiska pobranego z przekrojów „wodopój” (A, B, C) oraz „ujście” (D, E, F)

Fig. 2. Diagrams of grain size distribution curve of bed load taken from the cross section "water hole" (A, B, C) and the "mouth" (D, E, F) 
Tabela 1 . Wyniki obliczeń przepływu $(Q)$ oraz bezwymiarowej głębokości wody $(M)$

Table 1. Statement of the results discharge $(Q)$ and non-dimensional water depth $(M)$

\begin{tabular}{|c|c|c|c|c|c|c|c|c|c|c|}
\hline \multirow[t]{2}{*}{$\begin{array}{l}\text { Data } \\
\text { pomiaru }\end{array}$} & \multirow[t]{2}{*}{ 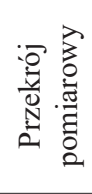 } & \multirow{2}{*}{$\begin{array}{c}\begin{array}{c}\text { Promień } \\
\text { hydrauliczny }\end{array} \\
(\mathrm{m})\end{array}$} & \multirow{2}{*}{$\begin{array}{c}\begin{array}{c}\text { Głębokość } \\
\text { wody } \\
(\mathrm{h} \max )\end{array} \\
(\mathrm{m})\end{array}$} & \multirow{2}{*}{$\begin{array}{c}\begin{array}{c}\text { Obwód } \\
\text { zwilżany }\end{array} \\
(\mathrm{m})\end{array}$} & $\begin{array}{c}\text { Przepływ Q } \\
\text { (na podstawie } \\
\mathrm{v}_{\mathrm{sr}} \text { ) }\end{array}$ & \multirow[t]{2}{*}{$\begin{array}{l}\text { Przepływ Q } \\
\text { (IMGW - } \\
\text { stacja } \\
\text { Proszówki) } \\
-1 \text { ) }\end{array}$} & \multirow[t]{2}{*}{$\Lambda$} & $\mathrm{M}_{2}$ & $\mathrm{M}_{3}$ & \multirow[t]{2}{*}{$\mathrm{M}_{4}$} \\
\hline & & & & & $\left(\mathrm{m}^{3} \cdot \mathrm{s}^{-1}\right)$ & & & \multicolumn{2}{|c|}{$(-)$} & \\
\hline 28.08 .2011 & & 0,415 & 0,67 & 40,00 & 18,3 & 10,9 & 0,433 & 0,561 & 0,697 & 0,903 \\
\hline 05.09 .2011 & :‡્ઞ & 0,272 & 0,52 & 37,49 & 10,4 & 7,4 & 0,370 & 0,438 & 0,651 & 0,771 \\
\hline 06.09 .2011 & 융유 & 0,228 & 0,44 & 34,69 & 7,7 & 5,9 & 0,353 & 0,403 & 0,679 & 0,775 \\
\hline 09.09 .2011 & & 0,428 & 0,80 & 39,51 & 8,0 & 5,7 & 0,670 & 0,795 & 1,250 & 1,484 \\
\hline 13.09 .2011 & & 0,287 & 0,68 & 26,63 & 6,8 & 5,3 & 0,443 & 0,500 & 1,047 & 1,182 \\
\hline 28.08 .2011 & & 0,539 & 0,75 & 33,25 & 16,3 & 10,8 & 0,568 & 0,695 & 0,789 & 0,965 \\
\hline 05.09 .2011 &.$\triangleq \widehat{\Xi}$ & 0,435 & 0,66 & 35,62 & 11,1 & 7,4 & 0,563 & 0,690 & 0,854 & 1,046 \\
\hline 06.09 .2011 & 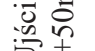 & 0,364 & 0,63 & 35,87 & 8,23 & 5,9 & 0,550 & 0,647 & 0,951 & 1,120 \\
\hline 09.09.2011 & $b^{t}$ & 0,360 & 0,61 & 35,21 & 6,7 & 5,7 & 0,599 & 0,650 & 1,014 & 1,100 \\
\hline 13.09 .2011 & & 0,333 & 0,56 & 35,19 & 5,8 & 5,3 & 0,593 & 0,621 & 0,997 & 1,044 \\
\hline
\end{tabular}

przepływu uzyskano w wyniku przyjęcia do jego obliczeń współczynników szorstkości związanych z głębokością wody w korycie lub z wielkością promienia hydraulicznego (w tym z parametrem $M$ ). Z punktu widzenia praktyki inżynierskiej do obliczeń wielkości przepływu wskazane jest stosowanie formuł empirycznych uwzględniających średnice ziaren rumowiska.

\section{Wnioski}

Wyniki przeprowadzonych badań wskazują na zmiany wartości współczynnika szorstkości $(n)$ przy stałej śred- nicy ziaren rumowiska i różnym napełnieniu w korycie. Trudno jednakże stwierdzić, czy istnieje bezpośredni związek między współczynnikiem szorstkości a głębokością wody.

Współczynnik szorstkości obliczony wg formuły: Stricklera $\left(n_{5}\right)$ oraz Stricklera w modyfikacji Gładki $\left(n_{6}\right)$, uwzględniający średnicę charakterystyczną $\left(d_{50}, d_{80}\right)$ przyjmuje wartości zbliżone do wartości obliczonych wg formuły Ven Te Chow $\left(n_{7}\right)$.

Najwyższe wartości współczynnika oporów przepływu $(f)$ występują w tej części koryta, którego dno pokrywają ziarna o średnicy odpowiadającej grubym i drobnym żwirom.
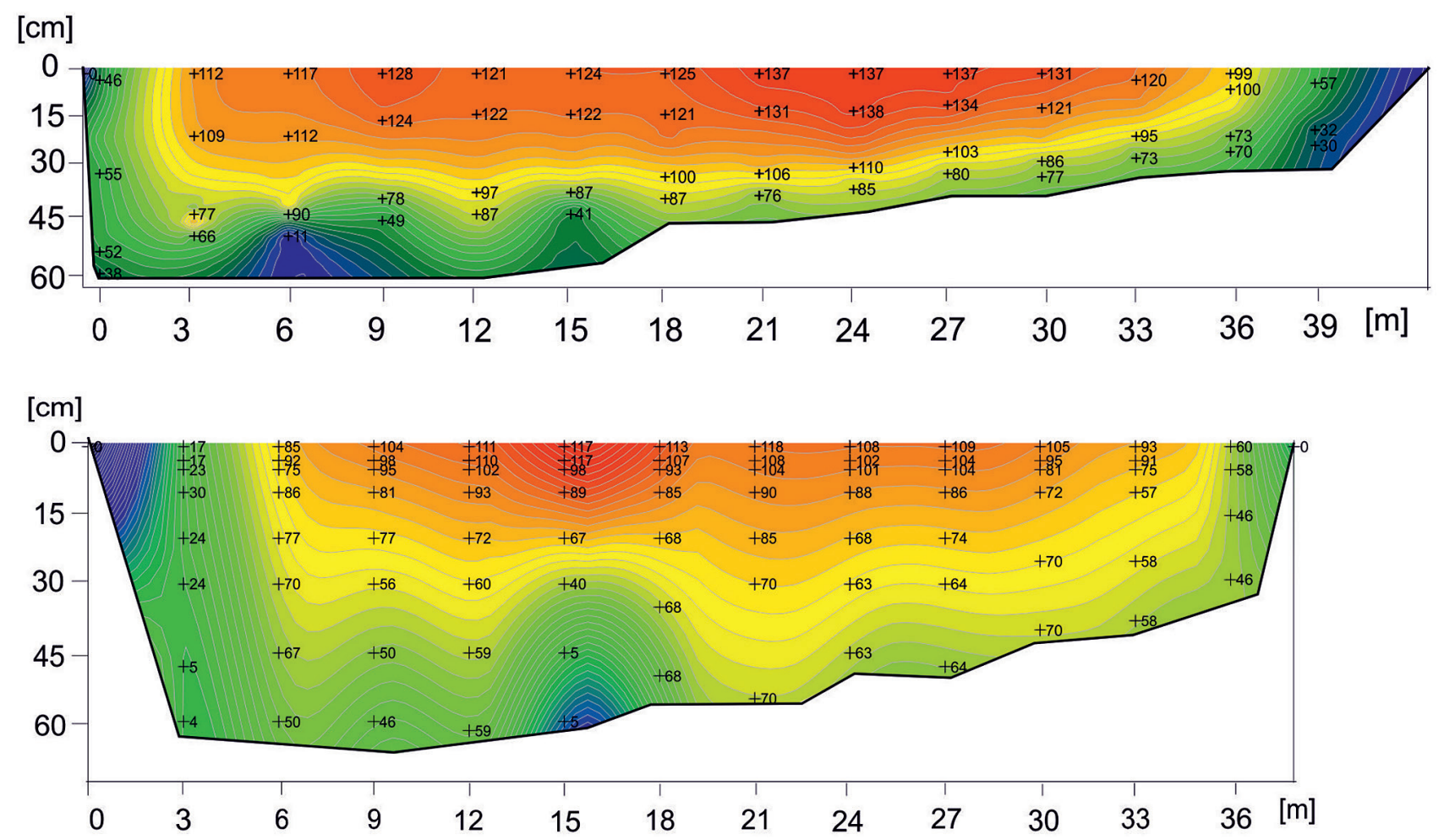

Ryc. 3. Wykresy rozkładu prędkości $\left(\mathrm{cm} \mathrm{s}^{-1}\right)$ w dwóch przekrojach badawczych

Fig. 3. Patterns of velocity $\left(\mathrm{cm} \mathrm{s}^{-1}\right)$ distribution in two research cross sections 
Tabela 2. Zestawienie wyników obliczeń współczynnika szorstkości $(n)$ wg różnych formuł oraz współczynnika oporów $(f)$

Table 2. Statement of results of roughness coefficient calculations $(n)$ by using different formulas and resistance factor $(f)$

\begin{tabular}{|c|c|c|c|c|c|c|c|c|c|}
\hline Przekrój & Data pomiaru & $n_{1}$ & $n_{2}$ & $n_{3}$ & $n_{4}$ & $n_{5}$ & $n_{6}$ & $n_{7}$ & $\mathrm{f}$ \\
\hline \multirow{5}{*}{ 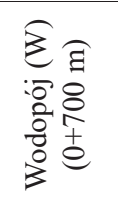 } & 28.08 .2011 & 0,023 & 0,038 & 0,019 & 0,032 & 0,035 & 0,024 & 0,016 & 0,039 \\
\hline & 05.09 .2011 & 0,018 & 0,026 & 0,015 & 0,021 & 0,030 & 0,018 & 0,024 & 0,053 \\
\hline & 06.09 .2011 & 0,017 & 0,022 & 0,014 & 0,018 & 0,040 & 0,019 & 0,018 & 0,030 \\
\hline & 09.09 .2011 & 0,053 & 0,075 & 0,043 & 0,061 & 0,035 & 0,016 & 0,019 & 0,052 \\
\hline & 13.09 .2011 & 0,022 & 0,028 & 0,016 & 0,021 & 0,045 & 0,016 & 0,016 & 0,049 \\
\hline \multirow{5}{*}{ 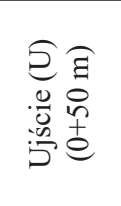 } & 28.08 .2011 & 0,033 & 0,049 & 0,029 & 0,044 & 0,035 & 0,016 & 0,016 & 0,053 \\
\hline & 05.09 .2011 & 0,036 & 0,053 & 0,031 & 0,047 & 0,040 & 0,024 & 0,024 & 0,054 \\
\hline & 06.09.2011 & 0,036 & 0,050 & 0,030 & 0,042 & 0,040 & 0,018 & 0,018 & 0,044 \\
\hline & 09.09.2011 & 0,043 & 0,050 & 0,036 & 0,042 & 0,030 & 0,019 & 0,019 & 0,053 \\
\hline & 13.09.2011 & 0,043 & 0,047 & 0,036 & 0,040 & 0,045 & 0,016 & 0,016 & 0,047 \\
\hline
\end{tabular}

Tabela 3. Zestawienie wyników obliczeń przepływu $(Q)$ z wykorzystaniem współczynnika szorstkości $(n)$ obliczonego wg różnych formuł

Table 3. Statement of results of discharge calculations $(Q)$ by using roughness coefficient $(n)$ calculated with different formulas

\begin{tabular}{|c|c|c|c|c|c|c|c|c|}
\hline \multirow{2}{*}{ Przekrój } & & \multicolumn{7}{|c|}{ Przepływ $Q_{n}\left(\mathrm{~m}^{3} \cdot \mathrm{s}^{-1}\right)$} \\
\hline & & $Q_{1}$ & $Q_{2}$ & $Q_{3}$ & $Q_{4}$ & $Q_{5}$ & $Q_{6}$ & $Q_{7}$ \\
\hline \multirow{5}{*}{\multicolumn{2}{|c|}{ Ujście (U) }} & 18,30 & 10,90 & 21,45 & 12,78 & 11,84 & 17,27 & 25,90 \\
\hline & & 10,44 & 7,44 & 12,60 & 8,98 & 6,42 & 10,70 & 8,02 \\
\hline & & 7,76 & 5,94 & 9,65 & 7,39 & 3,32 & 6,99 & 7,38 \\
\hline & & 8,06 & 5,72 & 9,92 & 7,04 & 12,30 & 26,90 & 22,65 \\
\hline & & 6,82 & 5,35 & 9,08 & 7,13 & 3,32 & 9,33 & 9,35 \\
\hline \multirow{5}{*}{\multicolumn{2}{|c|}{ Wodopój (W) }} & 16,34 & 10,90 & 18,23 & 12,16 & 15,21 & 33,26 & 33,26 \\
\hline & & 11,16 & 7,44 & 12,82 & 8,55 & 9,95 & 16,58 & 16,58 \\
\hline & & 8,23 & 5,94 & 9,88 & 7,13 & 7,45 & 16,55 & 16,55 \\
\hline & & 6,73 & 5,72 & 8,02 & 6,82 & 9,58 & 15,13 & 15,13 \\
\hline & & 5,87 & 5,35 & 6,97 & 6,36 & 5,60 & 15,76 & 15,76 \\
\hline \multirow{2}{*}{ Wartość średnia (Q) } & $\mathrm{U}$ & 10,27 & 7,07 & 12,54 & 8,66 & 7,44 & 14,24 & 14,66 \\
\hline & $\mathrm{W}$ & 9,66 & 7,07 & 11,18 & 8,2 & 9,56 & 19,46 & 19,46 \\
\hline
\end{tabular}

W praktyce inżynierskiej przyjmowanie do obliczeń zawyżonych wartości współczynnika szorstkości może prowadzić do błędnego wyznaczenia wielkości przepływu obliczeniowego.

\section{Podziękowania}

Pracę zrealizowano $\mathrm{w}$ ramach projektu badawczego $\mathrm{Nr}$ BM-4402/KIL, finansowanego przez Ministerstwo Nauki i Szkolnictwa Wyższego oraz Uniwersytet Rolniczy im. H. Kołłątaja w Krakowie. Dziękujemy dwóm anonimowym recenzentom za cenne uwagi do wcześniejszej wersji artykułu.

\section{Literatura}

Aberle J., Smart, G. M., 2003. The influence of roughness structure on flow resistance on steep slopes. Journal of Hydraulic Research 41(3): 259-269.

Bartnik W., Florek J., 2002. Charakterystyka parametrów przepływu w potokach górskich i na terenach zalewowych porośniętych roślinnością sztywną. Zeszyty Naukowe Akademii Rolniczej w Krakowie.

Bezzola G., Müller, A., Minor, H., 2004. Shallow open channel flow with large roughness. Int. Conf. Hydraulic Engineering: Research and Practice. Roorkee, India: 264-276.
Carling P. A., Kelsey, A., Glaister, M., 1992. Effect of bed roughness, particle shape, and orientation on initial motion criteria. Dynamics of gravel-bed rivers. Wiley \& Sons: 26-39.

Chow V. T., 1959. Open channel hydraulics. Mc Graw - Hill Book, New York.

Cowan W.L., 1956. Estimating hydraulic roughness cofficients. Agrcicultural Engineering 37(7).

Dąbkowski L., Skibiński J., Żbikowski A., 1982. Hydrauliczne podstawy projektów wodno- melioracyjnych. PWRiL, Warszawa.

Depeweg H., Krishna P.P., Nestor M., 2014. Sediment transport in irrigation canals: a new approach. UNESCO-IHE Delf Lecture Note Series.

Dynowska I. 1971. Typy reżimów rzecznych w Polsce. Zeszyty Naukowe UJ. Prace Geograficzne 28, 150.

Gładki H., 1976. Opory i prędkość przepływu w korytach rzek górskich na przykładzie karpackich dopływów Wisły. Zeszyty Naukowe Akademii Rolniczej w Krakowie, seria Rozprawy 43.

Gładki H., Michalik A., Bartnik W., 1981. Measurements of Bed load transport in mountain streams using the radioactive tracers method. Proc. Of Workshop IAHR, Rapperswil, USA.

Godzik M., 2006. Opory ruchu wody w strefie ekotonu brzegowego. Infrastruktura i ekologia terenów wiejskich $\mathrm{Nr} 4 / 2 / 2006$. Komisja Technicznej Infrastruktury Wsi: 17-27.

Hey R.D., 1988. Bar form resistance in gravel-bed rivers. Journal of Hydraulic Engineering - ASCE 114(12): 1498-1508.

Horn R., Richards K., 2007. Flow-Vegetation Interactions in Restored Floodplain Environments. W: P.J.Wood, D.M.Hannah and J.P.Sadler (eds.), Hydroecology and Ecohydrology: Past, Present and Future, John Wiley and Sons, Ltd. 
Julien P.Y., Klaassen G.J, Ten Brinke W.B., Wilbers A.W., 2002. Case study: bed resistance of Rhine River during 1998 flood. Journal of Hydraulic Engineering 128(12): 1042-1050.

Knighton D., 1984. Fluvial forms and processes. Edward Arnold Ltd, London.

Krzanowski S., 1972. Przestrzenna zmienność odpływu średniego (spływu jednostkowego) na obszarze Karpat polskich. Praca doktorska, MS.

Kubrak E., 2006. O obliczaniu przepustowości koryt rzecznych. Przegląd Naukowy, Inżynieria i Kształtowanie Środowiska 1(31): 29-38.

Lau Y.L., 1988. Roughness of reverse flow over dunes and its application to the modelling of the Pitt River. Canadian Journal of Civil Engineering 15: 547-552.

Mokwa M., 2003. Ocena oporów przepływu na terenach zalewowych rzeki Widawy w oparciu o zdjęcia lotnicze. Wydawnictwo AR Wrocław, Monografia.

Naudasher E., 1992. Hydraulik der Gerinnebauwerke. Springer Verlag.

Parker G., Peterson, A. W., 1980. Bar resistance of gravel-bed streams. Journal of the Hydraulics Division - ASCE 106(10): 1559-1573.

Parzonka W., Kasperek R., Bartnik W., 2002. Modelowanie transportu rumowiska wleczonego w korytach rzek z dnem aluwialnym na przykładzie górnej i środkowej Odry. Przegląd Naukowy, Inżynieria i Kształtowanie Środowiska XI 2(25): 70-79.

PN-EN 933-1, 2012. Badania geometrycznych właściwości kruszyw. cz.1. Oznaczanie składu ziarnowego - metoda przesiewania. PKN. Warszawa.
Punzet J., 1981. Empiryczny system ocen charakterystycznych przepływów rzek i potoków w karpackiej części Dorzecza Wisły. Wiadomości IMGW 1-2: 31-39.

Radecki-Pawlik A., Carling P.A., Słowik-Opoka E., Breakspeare R. 2005., Badania terenowe form żwirowo-piaszczystych w rzece o charakterze podgórskim. Infrastruktura i Ekologia Terenów Wiejskich, Komisja Technicznej Infrastruktury Wsi 4: 119-133.

Rice C. E., Kadavy K.C, Robinson K.M., 1998. Roughness of loose rock riprap on steep slopes. Journal of Hydraulic Engineering - ASCE 124(2):179-185.

Salata T., 2012. Realizacja pomiarów geodezyjnych wykorzystywanych do obliczeń hydrologicznych. Infrastruktura i Ekologia Terenów Wiejskich, Komisja Technicznej Infrastruktury Wsi 3/2: 133-144.

Słowik-Opoka E., 2006. Warunki hydrauliczne kształtujące dno rzeki o podłożu żwirowo-piaszczystym. Rozprawa doktorska. MS, AR w Krakowie.

Smart G.M., Duncan M.J., Walsh J.M., 2002. Relatively rough flow resistance equations. Journal of Hydraulic Engineering - ASCE 128(6): 568-578.

Wołoszyn J., Czamara W., Eliasiewicz R., Krężel J., 1994. Regulacja rzek i potoków. AWR, Wrocław.

Wrzesiński D., 2010. Przestrzenne zróżnicowanie stabilności reżimu odpływu rzek europejskich. Bogucki Wydawnictwo Naukowe, Studia i Prace z Geografii i Geologii 3.

Żelazo J., 1992. Badania prędkości i oporów przepływu w naturalnych korytach rzek nizinnych. Seria Monografie Naukowe. SGGW Warszawa: $1-148$. 